\title{
Heavy Metal Deposition in Soils and Plants Impacted by Anthropogenic Modification of Two Sites in the Sudan Savanna of North Western Nigeria
}

\author{
Sunday Paul Bako, \\ Augustine Uwanekwu Ezealor and Yahuza Tanimu \\ Additional information is available at the end of the chapter \\ http://dx.doi.org/10.5772/57299
}

\section{Introduction}

Heavy metals occur naturally in the ecosystem, most of them in trace quantities [1]. Depending on their concentration, some of them like $\mathrm{Zn}, \mathrm{Fe}, \mathrm{Mn}$ and $\mathrm{Cu}$ are essential plant nutrients [2, 3 , 4], others like $\mathrm{Pb}, \mathrm{Hg}$ and $\mathrm{Cr}$ do not have any known use to plants.

Deposition of heavy metals in soils from anthropogenic activities have been implicated for an increase in heavy metal concentration above background and recommended levels [5, 6, 7]. Heavy metals are important components of agro-allied products such as pesticides, herbicides, fertilizers; manufacturing and other synthetic products such as paints and batteries [8]. Mining activities, industrial, municipal and domestic wastes have been reported to be important sources of heavy metal pollution to the environment [9].

Combustion of fuel from petroleum, abrasion of tyres, brake lining, corrosion of the body work of vehicles and engine wear have been associated with elevated concentrations of $\mathrm{Cd}, \mathrm{Cu}, \mathrm{Mn}$, $\mathrm{Ni}, \mathrm{V}$ and $\mathrm{Zn}[10,11,12,13]$.

Excessive concentration of heavy metals in the environment is of great concern because of their non-biodegradability. Therefore, their persistence in the environment portends health hazard to plants and animals and consequently trigger ecological imbalance in the ecosystem [14]. Another concern that high concentrations of heavy metals raise is their ability to bioaccumulate across the food chain, with members that are high up the food chain having concentration of such metals several times higher than what is obtainable in the environment $[15,16,17]$. 
The effect of metals in living organisms could be chronic, due to exposures over a long period of time as a result of food chain transfer or acute poisoning due to ingestion or dermal contact [18]. The concentration of heavy metals in the shoot of plants may vary with season as a result of inherent growth dynamics of the plant; metal concentration and its bio-availability in the environment. Data on the response of plants to anthropogenic modification of the environment, particularly in relation to soil and air pollution by heavy metals in northern Nigeria is limited and includes earlier assessments $[3,6,15,16]$ and more recently [19], in which an attempt was made to document the visual symptoms expressed by some ruderal plant species in relation to air pollution as a step towards developing a reference for field identification of pollution events [19].

This study was carried out to determine the spatial and seasonal variations of heavy metal deposition in soils and plants in Nigeria's Sudan Savanna in order to assess the extent of pollution and to identify indigenous plant species that may be pollution tolerant and thus have potential for use in phytorememediation of heavy metal polluted sites.

\section{Materials and methods}

\subsection{Study area}

The two sampling sites were located in Katsina State, a state that falls within the Sudan Savanna eco-region of northern Nigeria (See Fig 1).

The Katsina Steel Rolling Mill (See Fig 2) was established in the mid 1970s with an installed capacity of 207, $000 \mathrm{mts}$ per annum [20]

Zobe dam was constructed in 1977 to provide Portable water and for irrigation. It has a storage capacity of 170 Million cubic meters, a surface area of $39.6 \mathrm{~km}^{2}$ and supports 8137 ha of irrigated land (See Fig 3).

\begin{tabular}{ccccc}
\hline \multirow{2}{*}{ Location/Site } & \multicolumn{1}{c}{$\begin{array}{c}\text { Sampling } \\
\text { Stations }\end{array}$} & Longitude & Latitude & Altitude \\
\hline \multirow{2}{*}{ Katsina Steel Rolling Mill environs } & 1 & $73706.46 \mathrm{E}$ & $125724.72 \mathrm{~N}$ & $557 \mathrm{~m}$ \\
\cline { 2 - 5 } & 2 & $73710.23 \mathrm{E}$ & $125710.23 \mathrm{~N}$ & $553 \mathrm{~m}$ \\
\cline { 2 - 5 } Zobe Dam catchment & 3 & $73723.06 \mathrm{E}$ & $125723.07 \mathrm{~N}$ & $556 \mathrm{~m}$ \\
\cline { 2 - 5 } & 1 & $72756.40 \mathrm{E}$ & $122142.18 \mathrm{~N}$ & $510 \mathrm{~m}$ \\
\hline
\end{tabular}

Table 1. Geographical Positioning Coordinates of sampling stations at Katsina Steel Rolling Mill environs and Zobe Dam catchment, Katsina state, north Western Nigeria. 


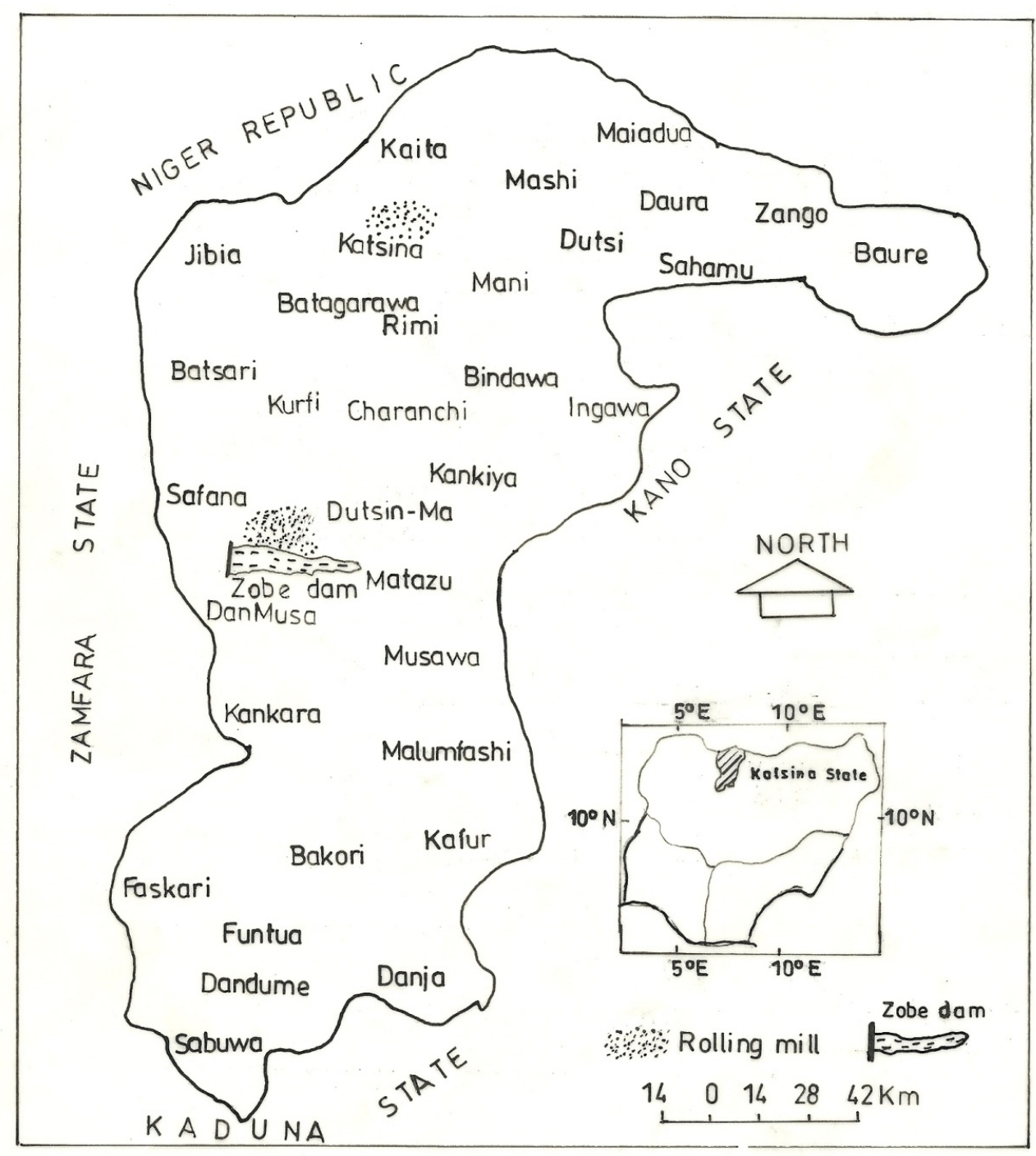

Figure 1. Katsina State, Nigeria showing approximate location of the Steel Rolling Mill and Zobe dam. 


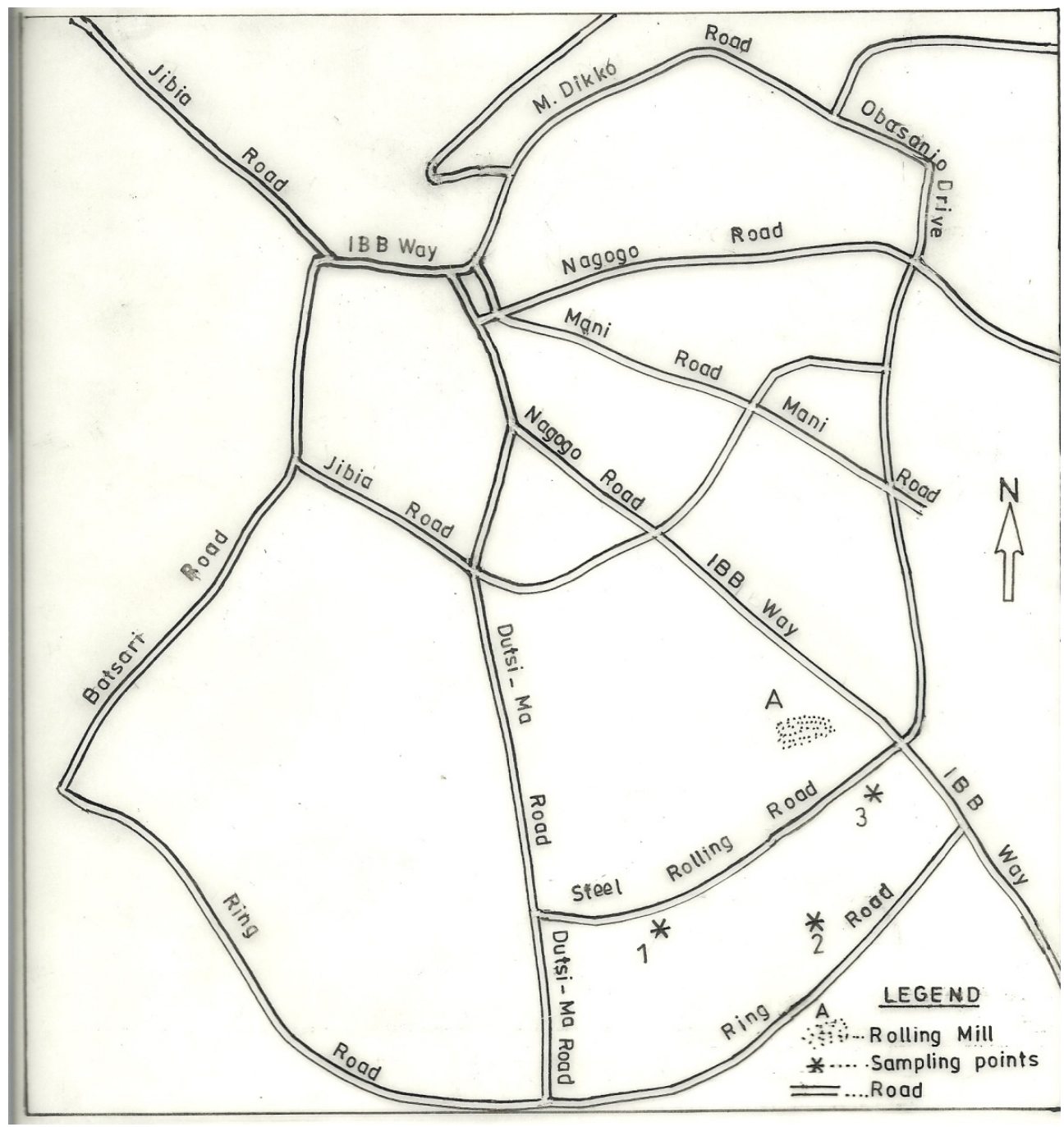

Figure 2. Environs of the Katsina Steel Rolling Mill Showing approximate sampling points. 


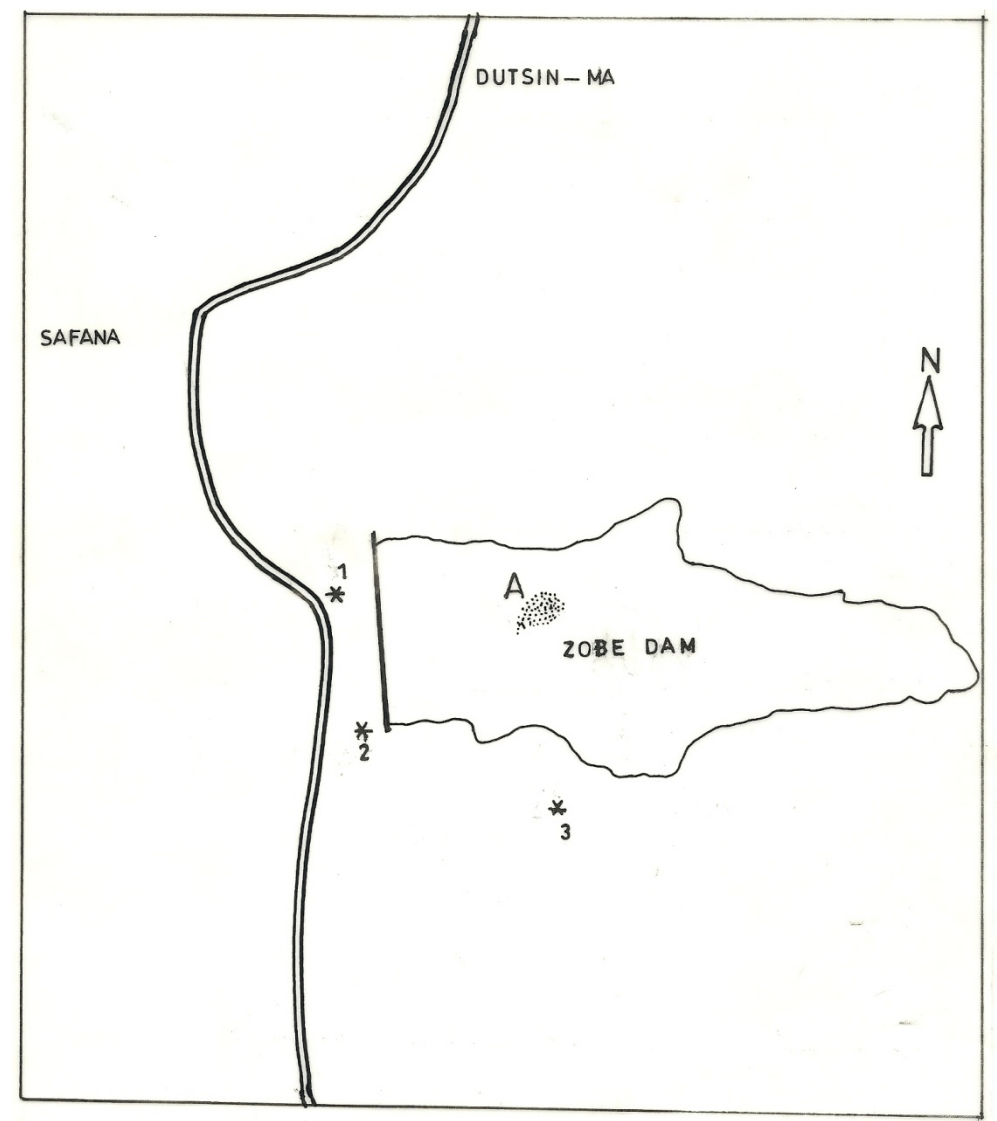

Figure 3. Environs of Zobe Dam showing approximate sampling points

\subsection{Sample collection}

Soil and plant samples were collected in both dry and wet seasons from three sampling stations per location in $5 \mathrm{~m}$ by $5 \mathrm{~m}$ quadrats. Soil samples were collected at $0-15 \mathrm{~cm}$ depth using a soil auger. The shoot of herbaceous plants with relative abundance greater than five per quadrat, were clipped with a pair of secateurs for heavy metal analysis. Identification of plant samples were confirmed in the herbarium of the Department of Biological Sciences, Ahmadu Bello University, Zaria. 


\subsection{Sample preparation}

Plant samples were washed with tap water and then with distilled water to remove debris and surface contamination. Samples were then bulked and air dried to remove excess moisture. Similarly, samples of the soils collected were bulked into composite samples and air dried for three days (72 hours).

Dried plant and soil samples were ground using a porcelain mortar and pestle and sieved to attain a uniform particle size. Each sample was put in a small transparent polythene bag and labeled.

\subsection{Metal analysis}

Analysis of the elemental content of the samples was done using the Energy dispersive X-ray fluorescence Spectroscopy (EDXRF) method [21].

The samples were ground manually to powder with an agate mortar and pestle to grain size of less than $125 \mu \mathrm{m}$. Pellets of $19 \mathrm{~mm}$ diameter were prepared from $0.3-0.5 \mathrm{~kg}$ powder mixed with three drops of organic liquid binder and pressed at 10 tons of pressure in a hydraulic press.

Measurements were performed using an annular $25 \mathrm{mCi}{ }^{109} \mathrm{Cd}$ as the excitation source, that emits $\mathrm{Ag}-\mathrm{K}$ rays $(22.1 \mathrm{KeV})$ in which case all elements with lower characteristic excitation energies are accessible for detection in the samples. The system consists furthermore of $\mathrm{Si}(\mathrm{Li})$ detector, with a resolution of $170 \mathrm{eV}$ for the $5.90 \mathrm{KeV}$ line, coupled to a computer controlled ADC - card.

Quantitative analysis of the sample was done using the Emission Transmission (E-T) method and that involves the use of pure target material (Mo) to measure the absorption factors in the sample.

The Mo target served as a source of monochromatic X-rays, which are excited through the sample by primary radiation and then penetrate the samples on the way to the detector. In this way, the absorption factor is experimentally determined which the program uses in the quantification of concentration of the elements. In addition, the contribution to the Mo-K peak intensity by the $\mathrm{Zr}-\mathrm{K}$ is subtracted for each sample.

Sensitivity calibration of the system was performed using thick pure metal foils ( $\mathrm{Ti}, \mathrm{Fe}, \mathrm{Co}, \mathrm{N}$, $\mathrm{Zn}, \mathrm{Nb}, \mathrm{Zr}, \mathrm{Mo}, \mathrm{Sn}, \mathrm{Ta}$ and $\mathrm{Pb})$ and stable chemical compounds $\left.\left(\mathrm{K}_{2} \mathrm{CO}_{3}\right), \mathrm{CaCO}_{3}, \mathrm{Ce}_{2} \mathrm{O}_{3}\right), \mathrm{WO}_{3}$, $\mathrm{ThO}_{2}, \mathrm{U}_{3} \mathrm{O}_{3}$ ). The spectra for the samples were collected for 3000 s with the ${ }^{109} \mathrm{Cd}$ source and the spectra were then evaluated using the AXIL-QXAS program [22]. ${ }^{109} \mathrm{Cd}$ source was used for the analysis of $\mathrm{K}, \mathrm{Th}, \mathrm{Y}, \mathrm{Zr}, \mathrm{Nb}$ and $\mathrm{Mo}$.

The accuracy and precision of the measurements was confirmed though an analysis of IAE V10 (hay powder) and IAEA - 259 (cabbage) certified reference material, distributed by International Atomic Energy Agency (IAEA). 


\subsection{Bioconcentration factor (Enrichment Coefficient) [23]}

This estimates the capacity of plants to accumulate metals, and was computed for each species as:

$$
\mathrm{BCF}=\frac{\text { Mean concentration of metal in the plant }}{\text { Mean concentration of metal in the soil }}
$$

\section{Results}

\subsection{Metal concentration in soils and plant samples}

In the soils around the Zobe dam catchment, the mean concentration of metals generally followed the order $\mathrm{Fe}>\mathrm{Mn}>\mathrm{Zn}>\mathrm{Cr}>\mathrm{Cu}>\mathrm{Ni}>\mathrm{Cd}$ and $\mathrm{Fe}>\mathrm{Mn}>\mathrm{Zn}>\mathrm{Ni}>\mathrm{Cr}>\mathrm{Cu}>\mathrm{Cd}$ in dry and wet seasons respectively. In soils in the environs of the Katsina Steel Rolling Mill (KTSRM), the mean wet season concentration trend followed the order $\mathrm{Fe}>\mathrm{Mn}>\mathrm{Zn}>\mathrm{Cr}>\mathrm{Ni}>\mathrm{Cu}>\mathrm{Cd}$ and $\mathrm{Fe}>\mathrm{Mn}>\mathrm{Zn}>\mathrm{Cu}>\mathrm{Cr}>\mathrm{Ni}>\mathrm{Cd}$ in the dry season (Table 2; Fig 4). Differences in soil concentrations of all the metals between seasons were not statistically significant $(\mathrm{P}=0.05)$

\subsection{Chromium}

The soil around the Zobe dam catchment had a mean Cr concentration of $66.00 \mathrm{mg} / \mathrm{kg}$ and $70.53 \mathrm{mg} / \mathrm{kg}$, in dry and wet seasons respectively (Table 2; Fig 4). The mean Cr concentration in the environs of the Katsina Steel Rolling Mill was $46.67 \mathrm{mg} / \mathrm{kg}$ in the dry season and $70.53 \mathrm{mg} /$ $\mathrm{kg}$ in the wet season. The wet season concentrations were observed to be higher than acceptable limits for soils in Canada and the Netherlands (Table 3).

\begin{tabular}{|c|c|c|c|c|c|c|c|c|}
\hline \multirow{2}{*}{\multicolumn{2}{|c|}{ Sampling Locations Seasons and P Values }} & \multicolumn{7}{|c|}{ Metals } \\
\hline & & $\mathrm{Cr}$ & $\mathrm{Cu}$ & $\mathrm{Ni}$ & Cd & $\mathrm{Fe}$ & Mn & Zn \\
\hline \multirow{3}{*}{ Zobe Dam } & DRY & 66.00 & 29.66 & 26.87 & 0.15 & 22700.00 & 360.58 & 263.33 \\
\hline & WET & 70.53 & 7.92 & 184.57 & 1.05 & 55516.93 & 891.66 & 428.45 \\
\hline & P value & $0.13 \mathrm{~ns}$ & $0.33 n s$ & $0.64 n s$ & $0.29 \mathrm{~ns}$ & $0.25 n s$ & $0.33 \mathrm{~ns}$ & $0.34 \mathrm{~ns}$ \\
\hline \multirow{3}{*}{ KTSRM } & DRY & 46.67 & 56.91 & 46.31 & 0.33 & 18266.67 & 277.22 & 693.67 \\
\hline & WET & 69.58 & 12.05 & 84.50 & 0.00 & 58867.00 & 745.75 & 385.00 \\
\hline & P value & $0.23 \mathrm{~ns}$ & $0.60 \mathrm{~ns}$ & $0.12 \mathrm{~ns}$ & & $0.32 \mathrm{~ns}$ & $0.17 \mathrm{~ns}$ & $0.94 \mathrm{~ns}$ \\
\hline
\end{tabular}

Differences in soil heavy metal content were not significant (ns) between seasons in both locations.

Table 2. Mean Seasonal Heavy Metal Concentration $(\mathrm{mg} / \mathrm{kg})$ and T-test P-values of Soils collected from Zobe dam catchment and the environs of Katsina Steel Rolling Mill (KTSRM) 


\begin{tabular}{|c|c|c|c|c|c|c|c|c|}
\hline \multicolumn{2}{|c|}{ Recommending Agency/Country } & $\mathrm{Cr}$ & $\mathrm{Cu}$ & $\mathrm{Ni}$ & $\mathrm{Cd}$ & $\mathrm{Fe}$ & Mn & $\mathrm{Zn}$ \\
\hline \multicolumn{2}{|l|}{ WHO [24] } & 100 & 30 & 80 & NA & NA & NA & 200 \\
\hline \multicolumn{2}{|c|}{ Mexico (Agricultural soils) [25] } & NA & NA & 1600.00 & 37.00 & NA & NA & NA \\
\hline \multicolumn{2}{|l|}{ USA [26] } & 3,000 & 4,300 & 75.00 & & NA & NA & 7500 \\
\hline \multicolumn{2}{|c|}{ Japanese MOE [27] } & 250 & NA & NA & 150 & NA & NA & NA \\
\hline \multirow{4}{*}{$\begin{array}{l}\text { Canadian } \\
\text { CCME [28] }\end{array}$} & Agriculture & 64 & 63 & 50 & 14 & NA & NA & NA \\
\hline & Residential/Park & 64 & 63 & 50 & 10 & NA & NA & NA \\
\hline & Commercial & 87 & 91 & 50 & 22 & NA & NA & NA \\
\hline & Industrial & 87 & 91 & 50 & 22 & NA & NA & NA \\
\hline \multicolumn{2}{|c|}{ Austria [29] } & 100 & 60 to 100 & 50 t0 70 & 1 to 2 & NA & NA & NA \\
\hline \multicolumn{2}{|c|}{ Germany [29] } & 60 & 40 & 50 & 1 & NA & NA & NA \\
\hline \multicolumn{2}{|c|}{ France [29] } & 150 & 100 & 50 & 2 & NA & NA & NA \\
\hline \multicolumn{2}{|c|}{ Luxembourg [29] } & $100-200$ & 50 to 140 & 30 to 75 & 1 to3 & NA & NA & NA \\
\hline \multicolumn{2}{|c|}{ Netherlands [29] } & 30 & 40 & 15 & 0.5 & NA & NA & NA \\
\hline \multicolumn{2}{|c|}{ Sweden [29] } & 60 & 40 & 30 & 0.4 & NA & NA & NA \\
\hline \multicolumn{2}{|c|}{ United Kingdom [29] } & 400 & 135 & 75 & 3 & NA & NA & NA \\
\hline
\end{tabular}

Table 3. International Recommended Levels of Heavy Metals in Soils ( $\mathrm{mg} / \mathrm{kg}$ )

In the plant samples, the highest concentration of Cr was recorded in Senna siberiana (2.64 mg/ $\mathrm{kg})$ in the dry season and Englerina gralicinus and Terminalia mollis $(3.30 \mathrm{mg} / \mathrm{kg})$ in the wet season (Fig 5). "Normal" concentration of Cr in plants is described as being from 0.1 to $0.5 \mathrm{mg} /$ $\mathrm{kg}$, while concentrations between 5 to $30 \mathrm{mg} / \mathrm{kg}$ as "Excessive" and 75 to $100 \mathrm{mg} / \mathrm{kg}$, "Phytotoxic" (Table 4).

\subsection{Copper}

Mean concentrations of $\mathrm{Cu}$ in the soil samples collected around the Zobe dam catchment was $29.66 \mathrm{mg} / \mathrm{kg}$ in the dry season and $7.92 \mathrm{mg} / \mathrm{kg}$ in the wet season. Around the environs of KTSRM, the mean Cu concentration was observed to be $56.91 \mathrm{mg} / \mathrm{kg}$ in the dry season and $12.05 \mathrm{mg} / \mathrm{kg}$ in the wet season (Table 2; Fig 4). Only soil samples collected from the environs of KTSRM in the dry season were observed to have mean $\mathrm{Cu}$ concentration above the acceptable limits of the WHO (30 mg/kg), Germany, the Netherlands and Sweden (40 $\mathrm{mg} / \mathrm{kg}$ ) Table 3).

In plant samples collected, the highest concentration of $\mathrm{Cu}$ was observed in members of the genus Diospyros, D. piscatoria, $10.41 \mathrm{mg} / \mathrm{kg}$ and D. mespiliformis $10.40 \mathrm{mg} / \mathrm{kg}$ in the dry season. In the wet season, the concentration of $\mathrm{Cu}$ was generally higher in the plants, with the highest 
concentration recorded in Combretum mucronatum (34.58 mg/kg) (Fig 5). Concentrations between 20 to $100 \mathrm{mg} / \mathrm{kg}$ in plants have been described as being excessive (Table 4).
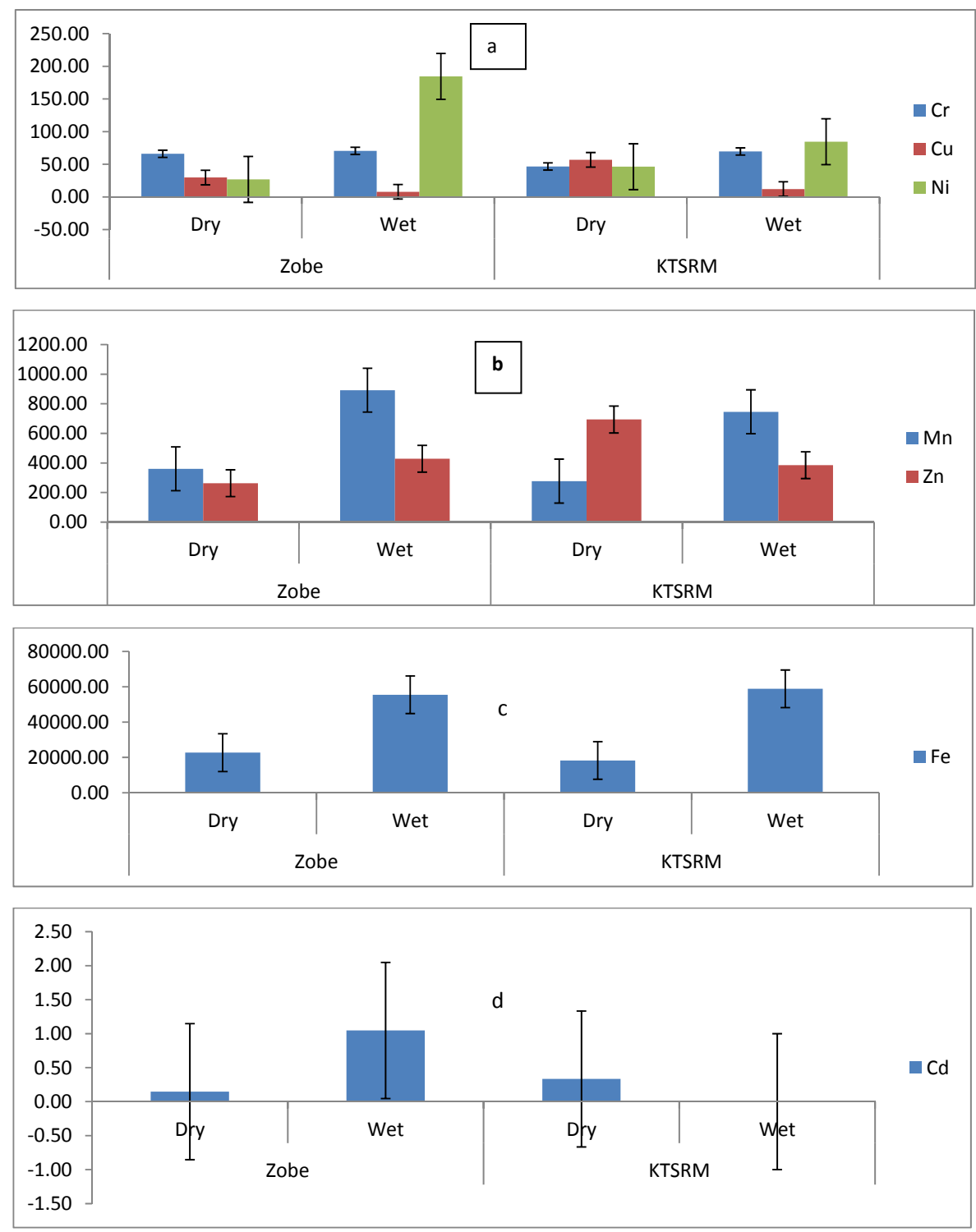

Figure 4. Seasonal variation in heavy metal concentration $(\mathrm{mg} / \mathrm{kg})$ in soils of Zobe dam catchment and the environs of Katsina Steel Rolling Mill (KTSRM)(a, Cu, Cr and Ni; b, Mn and $\mathrm{Zn} ; \mathrm{c}, \mathrm{Fe}$; and d, Cd). 


\begin{tabular}{ccccc}
\hline & NORMAL & DEFICIENCY & EXCESSIVE & PHYTOTOXIC \\
\hline $\mathbf{C d}$ & NA & NA & NA & 5 to 30 \\
\hline $\mathbf{Z n}$ & $27-150$ & 10 to20 & 100 to 400 & 70 to 400 \\
\hline $\mathbf{C r}$ & $0.1-0.5$ & NA & 5 to 30 & $75-100$ \\
\hline $\mathbf{C u}$ & $5.1-30$ & 2 to 5 & $20-100$ & $60-125$ \\
\hline $\mathbf{N i}$ & $0.1-5$ & NA & $10-100$ & 100 \\
\hline
\end{tabular}

Table 4. Range Values of Heavy Metals in Vegetation $(\mathrm{mg} / \mathrm{kg}$ )

\subsection{Nickel}

In soils around the Zobe dam catchment, the mean Ni concentration was $184.57 \mathrm{mg} / \mathrm{kg}$ in the wet season and $26.87 \mathrm{mg} / \mathrm{kg}$ in the dry season. Whereas mean concentrations of $\mathrm{Ni}$ of 46.31 $\mathrm{mg} / \mathrm{kg}$ and $84.50 \mathrm{mg} / \mathrm{kg}$ were observed in dry and wet seasons respectively, in soils around the environs of the KTSRM (Table 2; Fig 4). The mean concentration of Ni in both sites were observed to be higher than the acceptable limits of WHO $(80 \mathrm{mg} / \mathrm{kg})$, USA $(75 \mathrm{mg} / \mathrm{kg})$, Canada, France and Germany (50 mg/kg), Austria (50 to $70 \mathrm{mg} / \mathrm{kg}$ ), Luxembourg (30-75 mg/kg); and Netherlands, Sweden and the UK (Table 3).

In plant samples, Senna siberiana had the highest Ni concentrations of $3.69 \mathrm{mg} / \mathrm{kg}$ and 13.77 $\mathrm{mg} / \mathrm{kg}$ in dry and wet seasons respectively in the environs of KSTRM. Diospyros piscatoria was observed to have the highest concentration of $2.20 \mathrm{mg} / \mathrm{kg}$ for $\mathrm{Ni}$ in the dry season while Ipomoea ascarafolia had the highest concentration of $3.63 \mathrm{mg} / \mathrm{kg}$ among plants collected in the wet season around the Zobe dam catchment (Fig 5). Normal concentration of Ni in plants has been described to be between 0.1 to $5 \mathrm{mg} / \mathrm{kg}$, whereas concentrations between 10 to $100 \mathrm{mg} / \mathrm{kg}$ as excessive (Table 4).

\subsection{Cadmium}

Soils around the Zobe dam catchment had a mean Cd concentration of $0.15 \mathrm{mg} / \mathrm{kg}$ in the dry season and $0.33 \mathrm{mg} / \mathrm{kg}$ in the wet season. In the environs of KTSRM, a mean concentration of $1.05 \mathrm{mg} / \mathrm{kg}$ was observed in the dry season. In the wet season Cd concentrations were below detectable limits in the wet season (Table 2; Fig 4). The above mean concentrations were found to be within the acceptable limits of the WHO and the Countries listed in Table 3.

Ipomoeaascarafolia had the highest concentration of cadmium in dry $(3.90 \mathrm{mg} / \mathrm{kg})$ and wet $(1.03$ $\mathrm{mg} / \mathrm{kg}$ ) seasons among plants sampled around the Zobe dam catchment. In the environs of KTSRM, Ziziphus abyssinica was observed to have the highest concentration of $4.5 \mathrm{mg} / \mathrm{kg}$ of Cd in the dry season, while in the wet season Cadaba farinosa was observed to have the highest concentration of $0.54 \mathrm{mg} / \mathrm{kg}$ (Fig 5). 

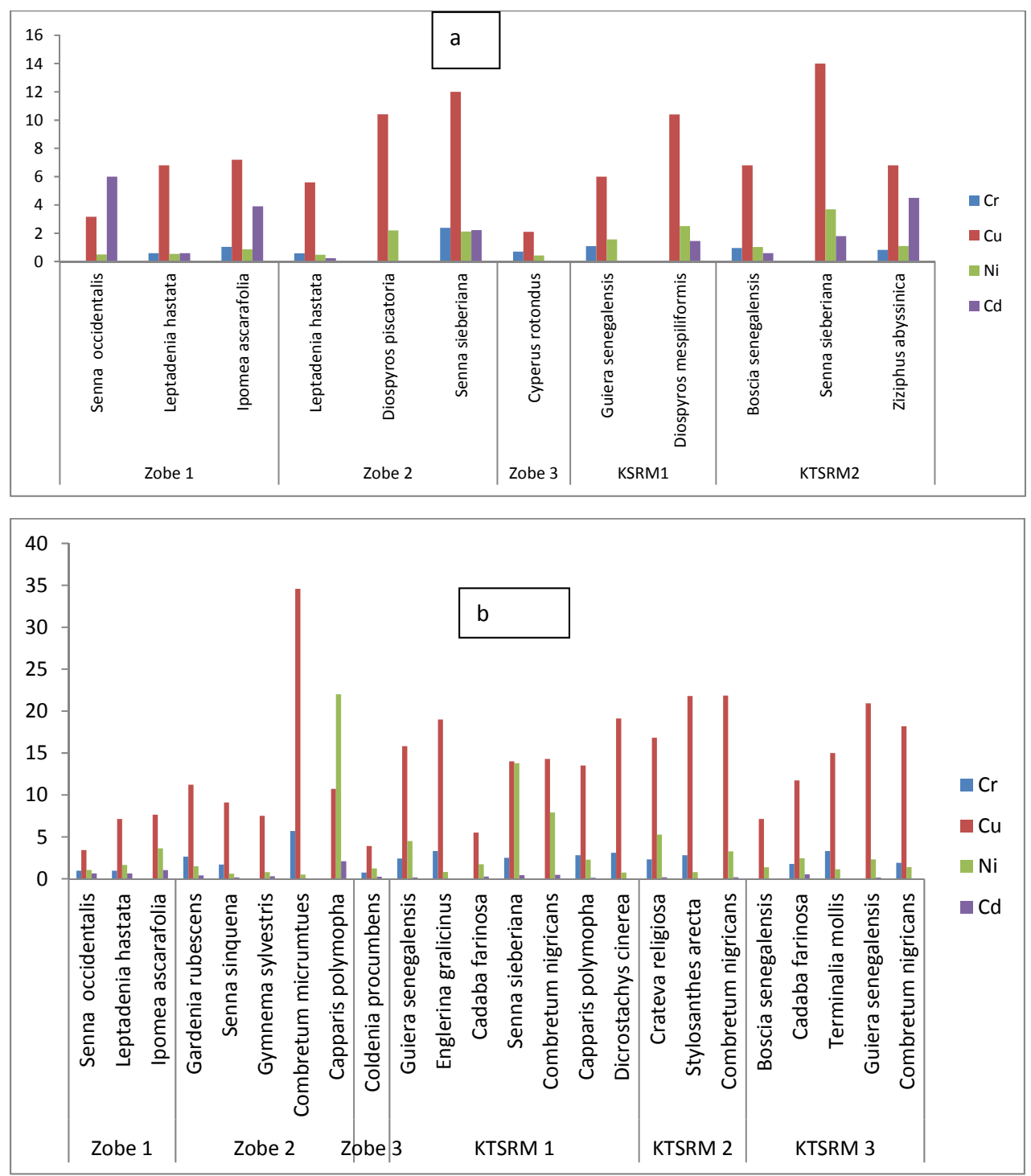

Figure 5. Concentration $(\mathrm{mg} / \mathrm{kg}$ ) of $\mathrm{Cr}, \mathrm{Cu}, \mathrm{Ni}$ and $\mathrm{Cd}$ in plants collected from Zobe Dam catchment and the environs of Katsina Steel Rolling Mill (KTSRM) during the Dry (a) and Wet (b) Seasons 


\subsection{Iron}

Soils in the two study sites were observed to have a higher concentration of Fe in the dry season than in the wet season. Soils from Zobe dam catchment and the environs of KTSRM had means of 22,700 and $555,16.93 \mathrm{mg} / \mathrm{kg}$; and $18,266.67$ and $58867 \mathrm{mg} / \mathrm{kg}$ in dry and wet seasons, respectively (Table 2; Fig 4).

Soil samples collected in the wet season were observed to have a higher concentration of Fe (891.66 and $745.75 \mathrm{mg} / \mathrm{kg}$ in Zobe dam catchment and the environs of KTSRM, respectively) than the dry season (360.58 and $277.22 \mathrm{mg} / \mathrm{kg}$ in Zobe dam catchment and environs of KTSRM, respectively (Table 2; Fig 4).

Plant species with the highest concentration of Fe in the wet season were Ipomoea ascarafolia $(115.50 \mathrm{mg} / \mathrm{kg})$ and Guiera senegalensis $(264.10 \mathrm{mg} / \mathrm{kg})$ for Zobe dam catchment and environs of KTSRM, respectively. In the dry season, Coldenia procumbens $(184.00 \mathrm{mg} / \mathrm{kg})$ and Guiera senegalensis $(176.84 \mathrm{mg} / \mathrm{kg}$ ) were observed to have the highest concentration of Fe Zobe dam catchment and the environs of KTSRM, respectively (Fig 6).

\subsection{Manganese}

The mean concentration of Manganese in soils was observed to be higher in the wet season (891.66 and $745.75 \mathrm{mg} / \mathrm{kg}$ ) than in the dry season $(360.66$ and $277 \mathrm{mg} / \mathrm{kg}$ ) for Zobe dam catchment and KTSRM respectively.

In plants, Diospyros piscatoria $(36.5 \mathrm{mg} / \mathrm{kg}$ ) and Boscia senegalensis $(102.87 \mathrm{mg} / \mathrm{kg})$ were observed to have the highest Mn concentration during the dry season in Zobe dam catchment and environs of KTSRM, respectively. In the wet season, Capparis polymopha (syn. C. tomentosa) $(80.72 \mathrm{mg} / \mathrm{kg})$ and Senna siberiana $(190.60 \mathrm{mg} / \mathrm{kg})$ were observed to have the highest concentration of Mn in Zobe reservoir and KTSRM, respectively (Fig 6).

\subsection{Zinc}

Zn concentrations in soils showed a similar pattern with Mn and Fe in Zobe dam catchment during the dry season, being higher in the wet $(428.45 \mathrm{mg} / \mathrm{kg})$ than the dry season $(263.67 \mathrm{mg} /$ $\mathrm{kg}$ ). A reversed trend was observed in the environs of KTSRM, with the concentration being higher in the dry season $(693.67 \mathrm{mg} / \mathrm{kg})$ than the wet season $(385.00 \mathrm{mg} / \mathrm{kg})$ (Table 2; Fig 4). These observed mean concentrations of $\mathrm{Zn}$ were higher than the $200 \mathrm{mg} / \mathrm{kg}$ acceptable limit of the WHO.

Leptadeniahastata (38.5 mg/kg), Senna siberiana ( $54.84 \mathrm{mg} / \mathrm{kg}$ ) were observed to have the highest concentration of $\mathrm{Zn}$ in the dry season for Zobe dam catchment and the environs of KTSRM, respectively. In the wet season, the highest concentrations of $\mathrm{Zn}$ in plant samples were presented by Capparis polymopha (syn. C. tomentosa) $(158.50 \mathrm{mg} / \mathrm{kg}$ ) and Senna siberiana (132.60 $\mathrm{mg} / \mathrm{kg}$ ) (Fig 6). Normal concentrations of Zinc in plants fall between 27 to $150 \mathrm{mg} / \mathrm{kg}$. However, concentrations between 100 to $400 \mathrm{mg} / \mathrm{kg}$ may be considered Excessive, while from 70 to 400 $\mathrm{mg} / \mathrm{kg}$, as Phytotoxic (Table 4). This is dependent on the plant species in question. 

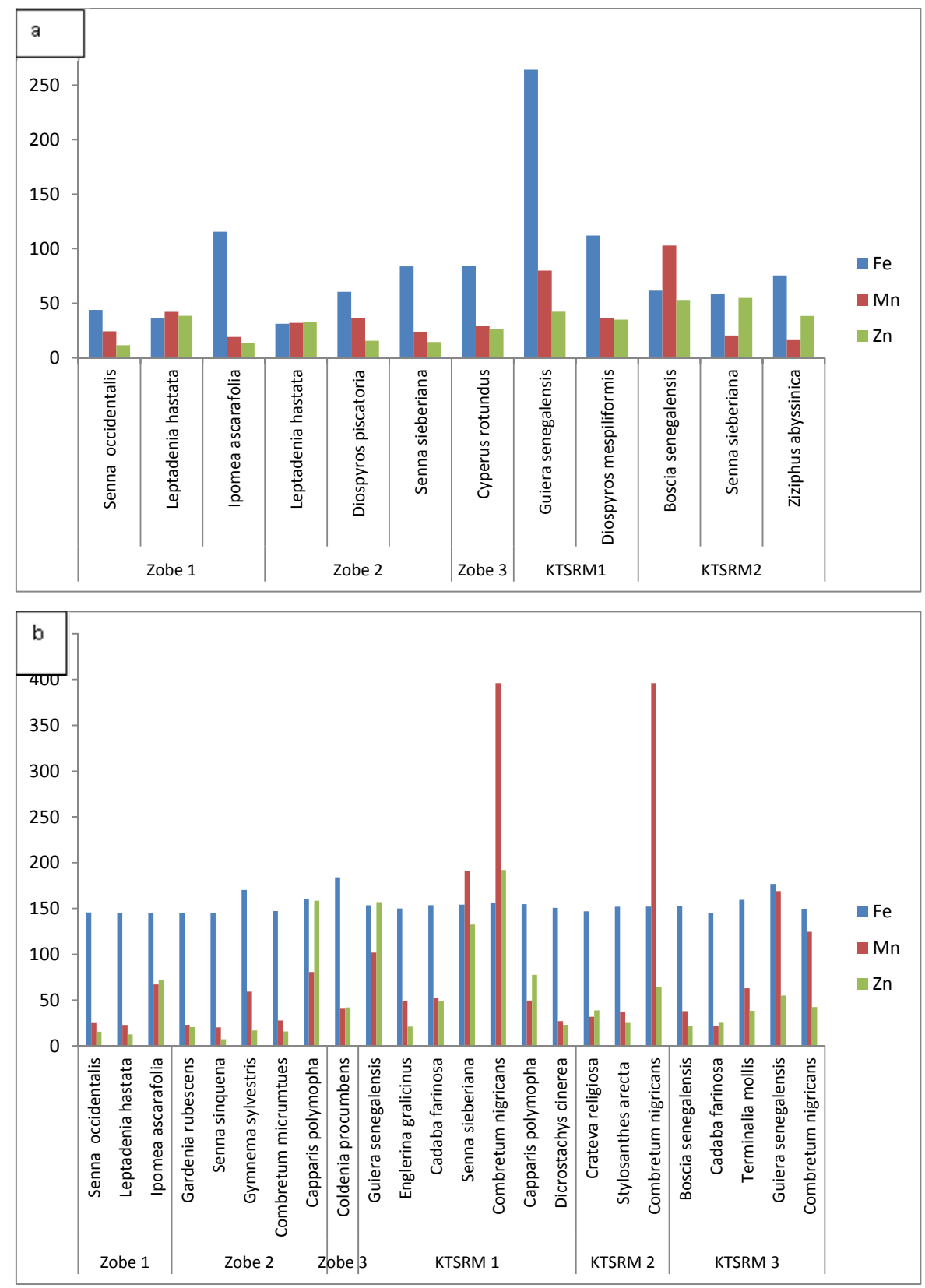

Figure 6. Concentration $(\mathrm{mg} / \mathrm{kg}$ ) of Fe, $\mathrm{Mn}$ and $\mathrm{Zn}$ in plants collected from Zobe dam catchment and the environs of Katsina Steel Rolling Mill (KTSRM) and the Dry (a) and Wet (b) Seasons 


\section{Bioconcentration Factor (BCF) of heavy metals in plants}

Chromium: $\mathrm{BCF}$ for $\mathrm{Cr}$ was generally low across seasons and site. In the two study areas, the BCF of $\mathrm{Cr}$ ranged between 0.00 to 0.03 in the dry season, while in the wet season it varied between 0.00 and 0.07. Combretummucronatum was observed to have the highest BF value (Fig. 7and 8).

Copper: BCF for $\mathrm{Cu}$ (Fig. 7 and 8) was generally higher in the wet season than in the dry season, with Combretum mucronatum having the highest value of 6.16. Ipomoea ascarafolia was observed to have the highest BF in the dry season. Across seasons and sites, other plant species that had BCF >1.0, were: Gardenia rubescens, Senna singuena, Gymnema sylvestris, Capparis polymopha, Guiera senegalensis, Englerina gracilinus, Senna siberiana, Combretum nigricans, Dicrostachys cinerea, Crateva religiosa, Stylosanthes arectalea and Terminalia mollis (Fig. 7 and 8).

Nickel: Highest BCF of Ni was observed in Combretumnigricans (1.61) and Capparis polymopha (syn. C. tomentosa) (0.61). Most plants show a higher BF during the wet season in comparison to the dry season (Fig. 7 and 8).

Iron: BCF of Fe was generally low, with the highest value of 0.07 observed in Sennasiberiana, across seasons and sites (Fig. 7 and 8 ).

Manganese: For Manganese, BCF was generally low (<1.0) (Fig. 9) across seasons and sites. In the wet season, Combretum nigricans was observed to show a high BF of 0.53 and 0.41 of $\mathrm{Mn}$ in two different replicate plots. Guiera senegalensis was observed to accumulate $\mathrm{Mn}$ to a BF of 0.38 . Boscia senegalensis was observed to have a BF of 0.62 during the dry season (Fig. 7 and 8).

Zinc: For Zinc, BCF was also generally low (<1.0) (Fig. 9) across seasons and sites.The highest BCF of Zn were observed in Ipomoea ascarafolia (0.70), Capparis polymopha (syn. C. tomentosa) (0.59), Guiera senegalensis (0.41) and Combretum nigricans (0.50) (Fig. 7 and 8).

Cadmium: Sennaoccidentalis and Ipomoea ascarafolia were observed to have considerably high BCF of 20.69 and 13.45 respectively. Most of the other plants were observed to have recorded higher BF in the wet season than the dry season. Across sites and seasons, other species that had BCF >1.0, were Leptadenia hastata, Capparis polymopha, Senna siberiana and Ziziphus abyssinica (Fig. 9)

Table 5 presents a summary of the most frequently accumulated metal in all species encountered at the sampling locations. Eighteen plant species were found to bioaccumulate metals $(\mathrm{BCF}>1)$ in their above ground part to varying degrees. $\mathrm{Cu}$ was the most frequently accumulated, being found to occur in all of the 18 species (100\%) across sites and seasons. This was followed by $\mathrm{Cd}$ in 6 species (33.33\%) and $\mathrm{Ni}$ in only one $(05.6 \%)$ species. 

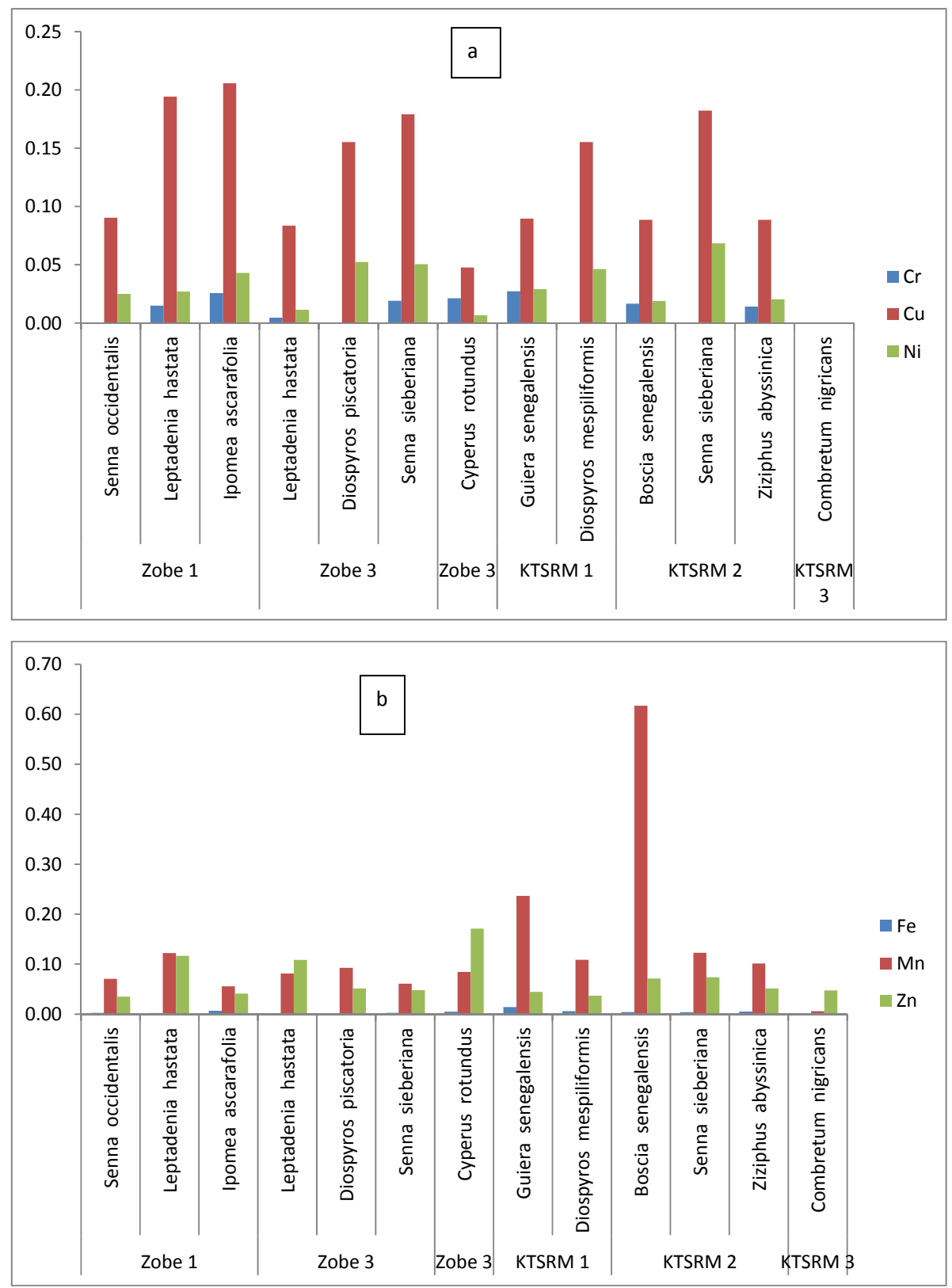

Figure 7. Bioconcentration of (a) $\mathrm{Cr}, \mathrm{Cu}$ and $\mathrm{Ni}$, (b) Fe, Mn and $\mathrm{Zn}$ in plants collected from Zobe dam catchment and the environs of Katsina Steel Rolling Mill during the Dry Season 

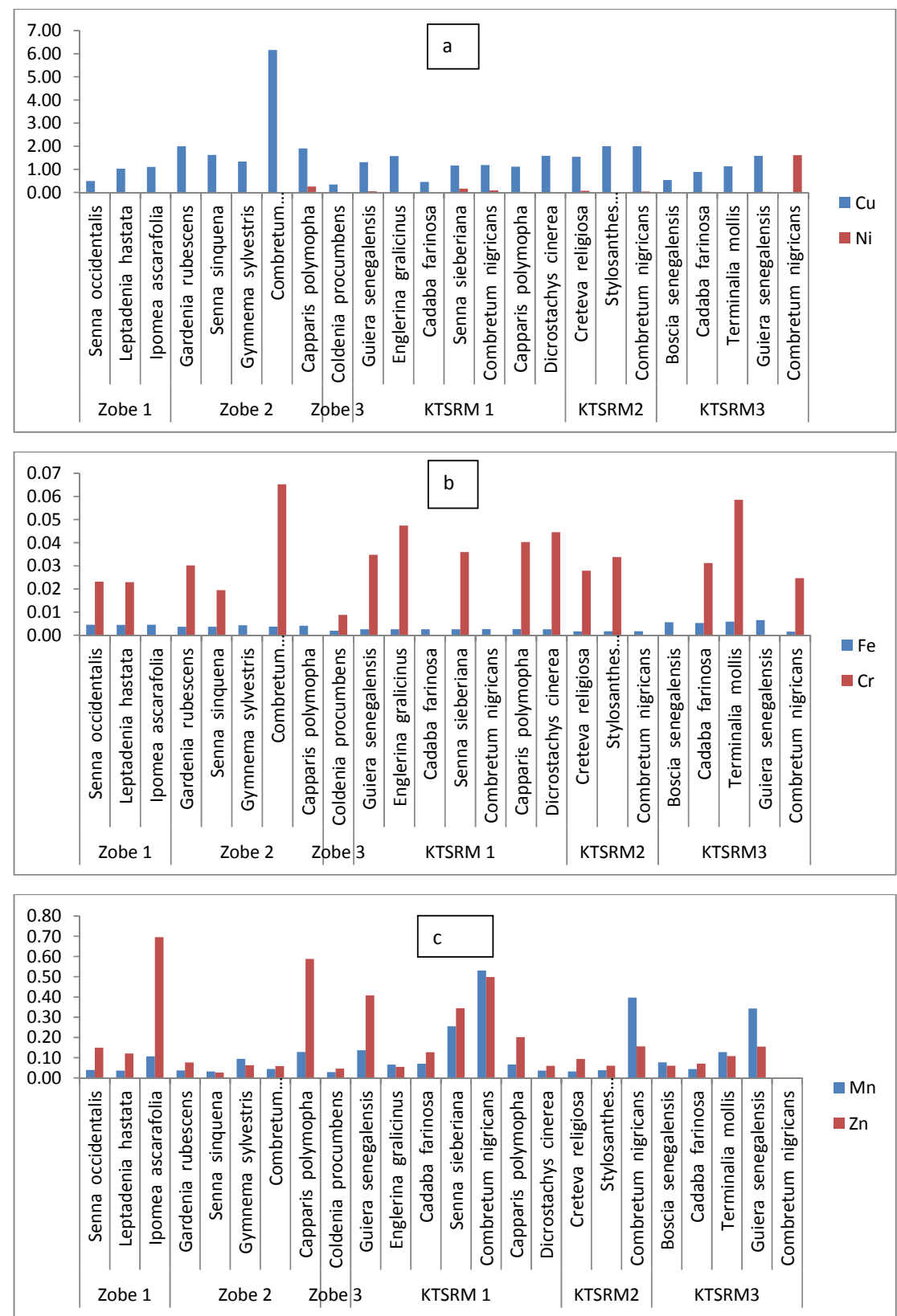

Figure 8. Bioconcentration of (a) $\mathrm{Cu}$ and $\mathrm{Ni}$, (b) Fe and $\mathrm{Cr}$, and (c) $\mathrm{Mn}$ and $\mathrm{Zn}$ in plants collected from Zobe dam catchment and the environs of Katsina Steel Rolling Mill during the Wet Season 


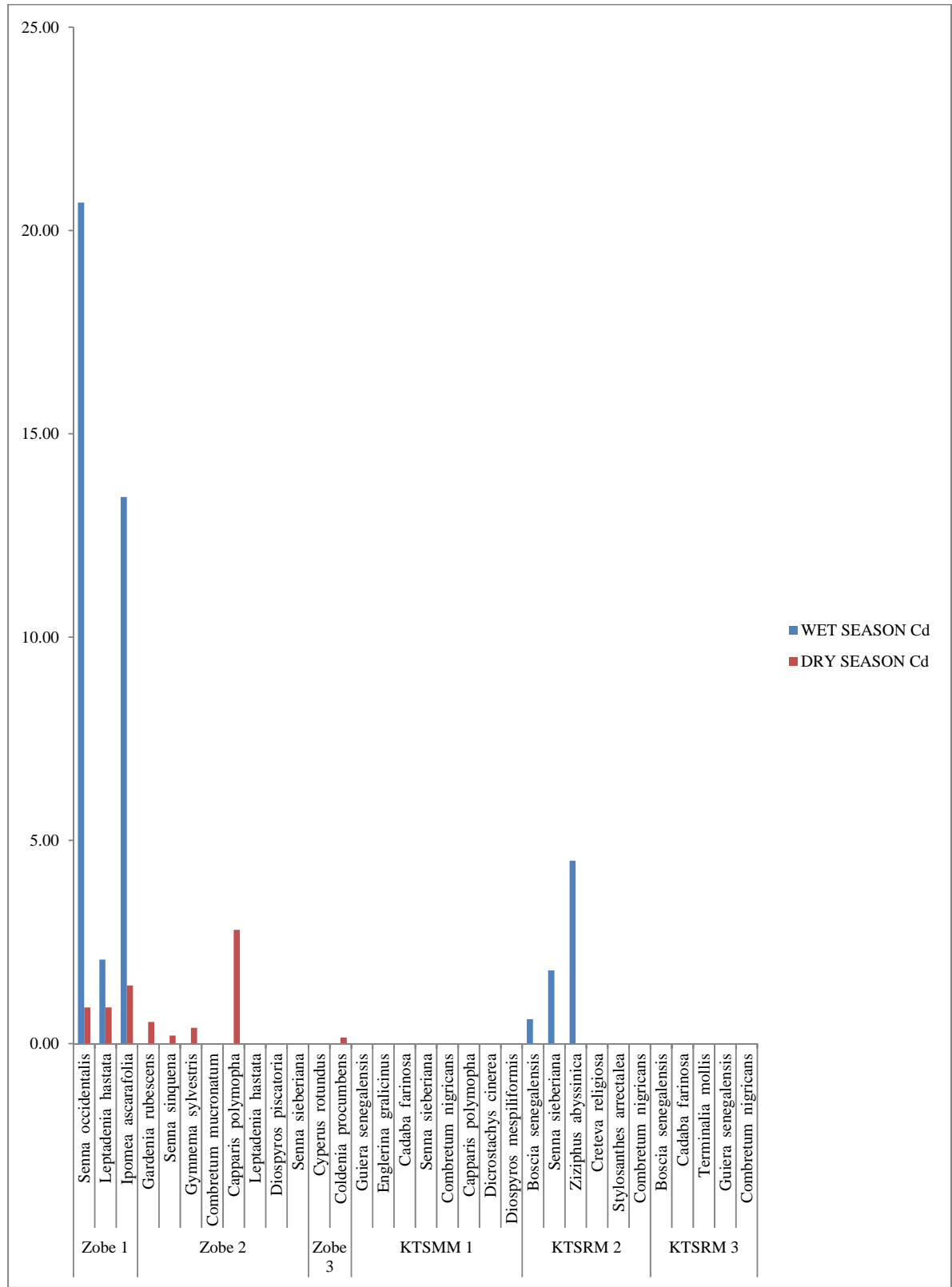

Figure 9. Bioconcentration of $\mathrm{Cd}$ in plants collected from Zobe dam catchment and the environs of Katsina Steel Rolling Mill during the Wet and Dry Seasons 


\begin{tabular}{|c|c|c|c|c|c|c|c|c|c|c|c|c|}
\hline \multirow[t]{3}{*}{ S/No. } & \multirow[t]{3}{*}{ Family } & \multirow[t]{3}{*}{ Plant Species } & \multicolumn{4}{|c|}{$\begin{array}{l}\text { Frequency of Occurrence } \\
\text { (\%) }\end{array}$} & \multicolumn{6}{|c|}{$\begin{array}{l}\text { Phtoextractive potential (as function of } \\
\qquad \text { BCF) }\end{array}$} \\
\hline & & & \multicolumn{2}{|c|}{ Zobe Dam } & \multicolumn{2}{|c|}{ KTSRM } & \multicolumn{2}{|c|}{$\mathrm{Cu}$} & \multicolumn{2}{|c|}{$\mathrm{Ni}$} & \multicolumn{2}{|c|}{$\mathrm{Cd}$} \\
\hline & & & Wet & Dry & Wet & Dry & Wet & Dry & Wet & Dry & Wet & Dry \\
\hline 1 & Caesalpiniaceae & $\begin{array}{l}\text { Sennaoccident } \\
\text { alis }\end{array}$ & 0 & 33 & 0 & 0 & - & - & - & - & - & + \\
\hline 2 & Asclepiadaceae & $\begin{array}{l}\text { Leptadeniahas } \\
\text { tata }\end{array}$ & 33 & 67 & 0 & 0 & + & - & - & - & - & + \\
\hline 3 & Convolvulaceae & $\begin{array}{l}\text { Ipomeaascaraf } \\
\text { olia }\end{array}$ & 33 & 33 & 0 & 0 & + & - & - & - & + & + \\
\hline 4 & Rubiaceae & $\begin{array}{l}\text { Gardeniarubes } \\
\text { cens }\end{array}$ & 33 & 0 & 0 & 0 & + & - & - & - & - & - \\
\hline 5 & Caesalpiniaceae & $\begin{array}{l}\text { Sennasinguen } \\
\text { a }\end{array}$ & 0 & 33 & 0 & 0 & + & - & - & - & - & - \\
\hline 6 & Asclepiadaceae & $\begin{array}{l}\text { Gymnemasylv } \\
\text { estre }\end{array}$ & 33 & 0 & 0 & 0 & + & - & - & - & - & - \\
\hline 7 & Combretaceae & $\begin{array}{l}\text { Combretumm } \\
\text { ucronatum }\end{array}$ & 33 & 0 & 0 & 0 & + & - & - & - & - & - \\
\hline 8 & Capparidaceae & $\begin{array}{l}\text { Capparispolym } \\
\text { opha }\end{array}$ & 33 & 0 & 0 & 0 & + & - & - & - & + & - \\
\hline 9 & Caesalpiniaceae & $\begin{array}{l}\text { Sennasieberia } \\
\text { na }\end{array}$ & 0 & 33 & 0 & 0 & + & - & - & - & - & - \\
\hline 10 & Combretaceae & $\begin{array}{l}\text { Guierasenegal } \\
\text { ensis }\end{array}$ & 0 & 0 & 66 & 33 & + & - & - & - & - & - \\
\hline 11 & Loranthaceae & $\begin{array}{l}\text { Englerinagralic } \\
\text { inus }\end{array}$ & 0 & 0 & 33 & 0 & + & - & - & - & - & - \\
\hline 12 & Combretaceae & $\begin{array}{l}\text { Combretumni } \\
\text { gricans }\end{array}$ & 0 & 0 & 100 & 0 & + & - & + & - & - & - \\
\hline 13 & Mimosaceae & $\begin{array}{l}\text { Dicrostachysci } \\
\text { nerea }\end{array}$ & 0 & 0 & 33 & 0 & + & - & - & - & - & - \\
\hline 14 & Caesalpiniaceae & $\begin{array}{l}\text { Sennasieberia } \\
\text { na }\end{array}$ & 0 & 0 & 33 & 33 & + & - & - & - & - & + \\
\hline 15 & Rhamnaceae & $\begin{array}{l}\text { Ziziphusabyssi } \\
\text { nica }\end{array}$ & 0 & 0 & 0 & 33 & - & - & - & - & - & + \\
\hline 16 & Capparidaceae & $\begin{array}{l}\text { Cratevareligios } \\
\text { a }\end{array}$ & 0 & 0 & 33 & 0 & + & - & - & - & - & - \\
\hline 17 & Papilionaceae & $\begin{array}{l}\text { Stylosanthesar } \\
\text { ectalea }\end{array}$ & 0 & 0 & 33 & 0 & + & - & - & - & - & - \\
\hline 18 & Combretaceae & $\begin{array}{l}\text { Terminaliamoll } \\
\text { is }\end{array}$ & 0 & 0 & 33 & 0 & + & - & - & - & - & - \\
\hline
\end{tabular}

$(+)=B C F>1 ;(-)=B C F<1$

Table 5. Seasonal occurrence of plant species with potential for phytoextraction (BCF) of Cu; Ni and Cd in the catchment of Zobe Dam and the environs of Katsina Steel Rolling Mill. 


\section{Discussion}

Concentrations of heavy metals in soils were generally observed to be higher during the wet season in both locations although the differences were not statistically significant $(\mathrm{P}=0.05)$. This differs somewhat with the findings of [30], who observed a higher concentration of these metals in the dry season than the wet season. Seasonal variations in patterns of metal deposition could be related to the intensity and duration of climatic variables such as precipitation, temperature etc., that interface with topography, drainage, soil structure/texture etc., to determine the physicochemical properties of the soil in a particular location. Soil physicochemical properties have complex, interdependent effects on metal solubility, with the most important of these including solution composition (inorganic and organic solubles), Eh, and $\mathrm{pH}$; type and density of charge on soil colloids; and reactive surface area, that interact with factors like metal concentration and form, particle size distribution, quantity and reactivity of hydrous oxides, mineralogy, degree of aeration and microbial activity [31]. The aggregate effects of these complex interactions determine the bioavailabilty of metals to plants.

The above acceptable limits of the observed concentrations of $\mathrm{Cr}, \mathrm{Cd}, \mathrm{Cu}, \mathrm{Ni}$ and $\mathrm{Zn}$ may be attributed to some of the human activities (mainly agriculture and industrial) going on around the sites. This presents health risks to humans and other animals as the metals contaminate both aquatic and terrestrial ecosystems. Above background values of these metals may have resulted from metal smelting and electroplating activities, burning of fossil fuels, application of phosphate fertilizers, disposal of solid wastes, and quarry activities [32, 33, 34, 35]. High levels of heavy metals in terrestrial or aquatic ecosystems ultimately end up being transmitted and accumulated in the food chain. Health risks to humans arise when metal polluted water is used as drinking water or when animals that have consumed vegetative materials in which metals have accumulated, are used for food. Furthermore, cultivation of crops on metal polluted soils indicates a possibility of consuming crops in which metals have accumulated. Although, specific effects of the various metals on human health have been discussed by several authors, the biotoxic effects of metals to humans have generally been outlined as ranging from gastrointestinal disorders, diarrhoea, stomatitis, tremor, hemoglobinuria, ataxia, paralysis, vomiting and convulsion, depression, coughing and wheezing, respiratory inflammation, dermatitis, leukocytis, low blood pressure, jaundice haemolytic anemia pneumonia and coma to death $(\mathrm{Cd}, \mathrm{Pb}, \mathrm{As}, \mathrm{Hg}, \mathrm{Zn}, \mathrm{Cu}, \mathrm{Cr}, \mathrm{Ni}$ and $\mathrm{Al})$. The nature of these effects could be toxic (acute, chronic or sub-chronic), neurotoxic, carcinogenic, mutagenic or teratogenic. For example, see $[15,16,40,41,42]$.

Concentration of $\mathrm{Cr}$ in all the plants observed was found to be below the 5 to $30 \mathrm{mg} / \mathrm{kg}$ described as phytotoxic to plants [35, 36]. The excessive to phytotoxic concentrations of $\mathrm{Zn}$ in Capparis polymopha (syn. C. tomentosa) and Guiera senegalensis; Cd in Senna occidentalis; Ni in Senna siberiana and $\mathrm{Cu}$ in Combretum mucronatum, may be a consequence of the high values observed in the soils or direct deposition from the atmosphere. In addition to soil concentrations of metals, other factors that determine the uptake, translocation and accumulation of metals in plants include soil $\mathrm{pH}$, cation exchange capacity, organic matter content, soil texture and interaction with other metals, as well as translocation factor (rate of movement of metals 
between root and shoot tissues) for the particular metal [43, 44]. Heavy metals in toxic concentrations within the plant have inhibitory effects on enzymatic activity, stomatal function, photosynthesis and nutrient uptake, which may be expressed visually as chlorosis, reduced/stunted growth and yield depression. Plants vary widely in their ability to tolerate high concentrations of metals in their tissues. This variation is usually natural and dependent on inherent genetic factors. The genetic disposition confers the ability to employ a range of avoidance/exclusion or detoxification mechanisms that enable the plants cope with high metal loads. These may include the binding of metals (e.g. Ni and $\mathrm{Cr}$ ) with amino acids, peptides and organic acids to form low molecular weight compounds, formation of phytochelatins, by binding (e.g. $\mathrm{Cu}$ and $\mathrm{Pb}$ ) with sulphur-rich proteins and cellular adaptations. Other strategies may involve roles for mychorrhizas, the cell wall, extra-cellular exudates, efflux pumping mechanisms in the plasma membrane and formation of stress proteins etc $[3,45,46,47]$.

Plants with BCF of metals $>1.0$, have been described as suitable for phytoextraction [37, 38]. Some of the plants observed in this study with this potential include; Combretum mucronatum, Ipomoea ascarafolia, Gardenia rubescens, Senna singuena, Gymnema sylvestre, Capparis polymopha (syn. C. tomentosa), Guiera senegalensis, Englerina gracilinus, Senna siberiana, Combretum nigricans, Dicrostachys cinerea, Crateva religiosa, Stylosanthes arectalea and Terminalia mollis for $\mathrm{Cu}$; Senna occidentalis, Ipomoea ascarafolia, Leptadenia hastata, Capparis polymopha (syn. C. tomentosa), Senna siberiana and Ziziphus abyssinica for Cd; Combretum nigricans for Ni. The ability of these plants to concentrate high levels of these metals suggests that they may have a good potential for phytoremediation.

No hyper-accumulator was observed in this study. Hyper-accumulators are plants that can accumulate at least $0.1 \%$ wt of $\mathrm{Cu}, \mathrm{Cd}, \mathrm{Cr}, \mathrm{Pb}, \mathrm{Ni}$ and $\mathrm{Co}$ or $1 \%$ wt of $\mathrm{Zn}$ and $\mathrm{Mn}$ [39]. There are possibilities for genetic modification of plants to enhance their capacity for metal tolerance [48].

\section{Recommendations for further research}

There is a great need to establish environmentally safe limits for metals in plant and soils of the various eco-regions in Nigeria. This need is emphasized by the observed variations in published background values from one country to another and even within the same country. These background values are often dependent on the geological history of the area. A comparison of observed field values with national recommended levels for heavy metals, developed from the background values will give a more realistic assessment of the pollution status. Furthermore, the search for alternative green technology that can be employed in remediation of pollution events must necessarily be a continuous one, due to the relative low cost and environmental friendliness of this option as compared to others. In this regard, ruderal species rather than those with agricultural value must be the candidates of choice for avoidance of obvious conflicts. The species that have indicated potentials for phytoextraction of $\mathrm{Cu}, \mathrm{Cd}$ and $\mathrm{Ni}$ in this research may therefore be further evaluated. 


\section{Conclusion}

The concentrations of $\mathrm{Cr}, \mathrm{Cu}, \mathrm{Ni}$ and $\mathrm{Zn}$ in soils around the Zobe dam catchment and the environs of Katsina Steel Rolling Mill were found to be above the acceptable limits. This presents health risks to humans and other animals as the metals contaminate both aquatic and terrestrial ecosystems.

Although no hyper accumulator plant species was encountered in this study, eighteen (18) plant species were identified to have high bioconcentration of metals, which indicated tolerance to excessive or phytotoxic metal concentrations. In addition, they generally produce high above ground biomass, due to rapid vegetative growth. These plants include: Combretum mucronatum, Ipomoea ascarafolia, Gardenia rubescens, Senna singuena, Gymnema sylvestre, Capparis polymopha (syn. C. tomentosa), Guiera senegalensis, Englerina gracilinus, Senna siberiana, Combretum nigricans, Dicrostachys cinerea, Crateva religiosa, Stylosanthes arectalea, Terminalia mollis, Senna occidentalis, Leptadenia hastata, and Ziziphus abyssinica. These present further possibilities for evaluating metal tolerance in relation to their potential use in phytoremediation programmes in metal polluted sites.

\section{Acknowledgements}

We wish to appreciate the University Board of Research of the Ahmadu Bello University, Zaria, Nigeria for providing the funds for this research. We also thank Mallam Gallah S. Umar who helped with the field identification of plant species and collection of plant/soil samples.

\section{Author details}

Sunday Paul Bako ${ }^{1}$, Augustine Uwanekwu Ezealor ${ }^{2}$ and Yahuza Tanimu ${ }^{1}$

*Address all correspondence to: spbako2002@yahoo.com

1 Department of Biological Sciences, Ahmadu Bello University, Zaria, Nigeria

2 Department of Forestry and Environmental Management, Michael Okpara University of Agriculture, Umudike, Nigeria

\section{References}

[1] Lar, U. A. Trace elements and health: an environmental risk in Nigeria. Earth Science, 2013; 2(3): 66-72. 
[2] An'ongo, M.C., Bako, S.P., Ezealor, A.U. Trace metal content in relation to populations of micro-organisms in soils along some highways in Nigeria's Guinea Savanna. Journal of Biological Sciences. 2005; 5(6): 703-706.

[3] Bako, S.P., Funtua, I.I., Ijachi, M. Heavy metal content of some Savanna plant species in relation to air pollution. Water, Air and Soil Pollution. 2005;161(1-4): 125-136.

[4] Tanimu, J., Uyovbisere, E. O., Lyocks, S.W.J., Tanimu, Y. Cowdung management on the calcium and magnesium content and total microbial population in the Northern Guinea Savanna of Nigeria. Global Journal of Biology, Agriculture and Health Sciences, 2013; 2 (2): 7-11.

[5] Maine, M. A., Sune, N. L., Lagger, C. Chromium bioaccumulation: comparison of the capacity of floating aquatic macrophytes. Water Research, 2004; 38: 1494-1501.

[6] Bako, S.P., Odiwo, J.E., Ezealor, A.U. Plant diversity in relation to anthropogenic Trace Metals in soils of selected sites in Nigeria's Guinea Savanna. International Journal of Environment and Pollution: Special issue on Biogeochemistry of toxic trace metals in Water, Soil and Plant, 2008; 33 (2/3):185-194.

[7] Tanimu, Y., Bako, S. P., Tiseer, F. A. Effects of sewage pollution on water quality of Samaru strea, Zaria, Nigeria. In: Fernando Sebastian Garcia Einschlag and Luciano Carlos (Eds). Waste Water: Treatment Technologies and Recent Analytical Developments, INTECH Publishers, Rijeka, Croatia. 2013; Pp 189-195.

[8] USDA (United States department of Agriculture). Heavy metal soil contamination. Soil Quality - Urban Technical Note, 2000; No. 3, 1-7.

[9] Mathews-Amune, O. C., Kakulu, S. Investigation of heavy metal levels in roadside agricultural soil and plant samples in Adogo, Nigeria. Academic Journal of Environmental Sciences, 2013; 1 (2):31-35.

[10] Albasel N., Cotteine A. In: Iyaka, Y. A. and Kakulu, S. E. Lead, Copper and Zinc Concentrations in Roadside Topsoil of Niger State, Nigeria. Journal of Emerging Trends in Engineering and Applied Sciences (JETEAS), 2011; 2 (5): 754-758

[11] Nyagababo, J. T., Hamya, J. W. In : Iyaka, Y. A., Kakulu, S. E. Lead, Copper and Zinc Concentrations in Roadside Topsoil of Niger State, Nigeria. Journal of Emerging Trends in Engineering and Applied Sciences (JETEAS), 2011; 2 (5): 754-758

[12] Munch, D. In : Iyaka, Y. A., Kakulu, S. E. Lead, Copper and Zinc Concentrations in Roadside Topsoil of Niger State, Nigeria. Journal of Emerging Trends in Engineering and Applied Sciences (JETEAS), 2011; 2 (5): 754-758

[13] Menaci, F., Bargagli, R. In : Iyaka, Y. A., Kakulu, S. E. Lead, Copper and Zinc Concentrations in Roadside Topsoil of Niger State, Nigeria. Journal of Emerging Trends in Engineering and Applied Sciences (JETEAS), 2011; 2 (5): 754-758 
[14] Ekmekyapar, F., Sabudak, T., Seren, G. Assessment of heavy metal contamination in soil and wheat (Triticum aestivum L.) plant around the Corlu-Cerkezkoy highway in Thrace region. Global Nest Journal, 2012; 14 (4): 496-504.

[15] Bako, S.P., Bhwankot, Edna S., Ezealor, A.U., Chia, A.M., Funtua, I.I. Human health implications of trace metal contents in parts of Maize (Zea mays L.) plants cultivated along highways in Nigeria's Guinea Savanna. Soil Remediation Series: Pollution Science, Technology and Abatement. Lukas Aachen and Paul Eichmann (Eds). Nova Science Publishers, Inc. Hauppauge, New York, United States of America, 2009; pp. 345-356 (Available on-line at www.novapublishers.com).

[16] Bako, S.P., Bhwankot, Edna S., Ezealor, A.U., Chia, A.M., Funtua, I.I. Human health implications of trace metal contents in parts of Cowpea (Vigna unguiculata L.Walp.) plants cultivated along highways in Nigeria's Guinea Savanna. Soil Remediation Series: Pollution Science, Technology and Abatement. Lukas Aachen and Paul Eichmann (Eds). Nova Science Publishers, Inc. Hauppauge, New York, United States of America 2009; pp.357-368(Available on-lineat www.novapublishers.com).

[17] Megateli, S., Semsari, S., Couderchet, M. Toxicity and removal of heavy metals (Cadmium, Copper, and Zinc) by Lemna gibba. Ecotoxicology and Environmental Safety, 2009; 72: $1774-1780$.

[18] Oti Wilberforce, J. O., Nwabue, F. I. Uptake of heavy metal by Discorea rotundata (white yam) and Ipomoea batatas (Sweet potato) from Enyingba lead-zinc derelict. Environment and Pollution, 2013; 2 (2): 79-84.

[19] Bako, S.P., Odiwo, J. E., Bako, Lois S.P. Visual symptoms expressed by some plant species in response to anthropogenic air pollution in Nigeria's Guinea Savanna. Mambilla: Journal of Sciences and the Environment, 2013; (in press)

[20] Dana Group. www.danagroup.com/Businesses/Dana-Group-Of-Companies/DanaSteel-Mill.aspx. 2013

[21] Funtua, I.I. Application of the transmission emission method in ED-XRF for the determination of trace element in geological and biological materials. Journal of Trace and Microprobe Techniques, 1999; 17, 293-297.

[22] Bernasconi, G.B. AXIL-QXAS, Instruction Manual. IAEA, Vienna, 1996; pp7-11

[23] Zu, Y. Q., Li, Y., Chen, J. J., Chen, H. Y., Qin, L., Schvartz, C. Hyperaccumulation of $\mathrm{Pb}, \mathrm{Zn}$, and $\mathrm{Cd}$ in herbaceous plants grown on lead-zinc mining area in Yunnan, China. Environment International, 2005; 31, 755-762.

[24] World Health Organization, (WHO). World Health Organization Guidelines for Drinking-Water Quality. 1996; 2nd Ed., Vol. 2, Health Criteria and Supporting Information, WHO, Geneva.

[25] Dávila, O. G., Gómez-Berna, J. M.l., Ruíz-Huerta, E. S. Plants and Soil Contamination with Heavy Metals in Agricultural Areas of Guadalupe, Zacatecas, Mexico Environ- 
mental Contamination, Dr. Jatin Srivastava (Ed.), 2012; ISBN: 978-953-51-0120-8, INTECH Publishers, Available from: http://www.intechopen.com/books/ environmental-contamination/plants-and-soil-contamination-with-heavymetals- inagricultural-areas-of-guadalupe-zacatecas-Mexico Osiel González Dávila, 1 Juan Miguel Gómez-Bernal2

[26] United States Environmental Protection Agency (USEPA). Clean Water Act, Section, 503: 1993; 58(32). www.epa.gov.

[27] MOE, Japan. Enforcement status of Agricultural Land-Soil Pollution Prevention Law in 2005 fiscal year. MOE, Japan, 2006; Available at: http:/ / w w w. e n v. g o. j p / w a t e r/d o jo / n o u y o / jokyo_h17.pdf

[28] Canadian Council of Ministers of the Environment. Canada environment quality guidelines. Published by the Canadian Council of Ministers of the Environment. Winipeg, Canada 2009; pp. 8.

[29] European Commission Director General, Environment, (ECDGE). Heavy metals and organic compounds from wastes used as organic fertilizers. Final Report, July 2010. WPA Consulting Engineers Inc. Ref. Nr. TEND/AML/2001/07/20, pp73-74. http;//ec.europa.eu/environment/waste/compost/pdf/hm_finalreport.pdf

[30] Najib, N. W. A.Z., Mohammed, S. A., Ismail, S. A., Amiza, W., Ahmad, W. A. Assessment of Heavy Metals in Soil due to Human Activities in Kangar, Perlis, Malaysia. IJCEE-IJENS, 2012; 12 (6): 28-33.

[31] Cataldo, D.A., Widung, R.E., soil and plant factors influencing the accumulation of heavy metals by plants. Environmental Health Perspectives, 1978; 27, 149-159.

[32] Alloway, B.J., The origins of heavy metals in soils. In: Alloway, B.J. (Ed.), Heavy Metals in Soils, Second Ed. Blackie Academic \& Professional Publishers, 1995.

[33] Knox, A.S., Gamerdinger, A.P., Adriano, D.C., Kolka, R.K., Kaplan, D.I. Sources and Practices Contributing to Soil Contamination. In: Adriano, D.C., Bollag, J.M., Frankenberg, W.T.Jr, Sims, R.C. (Eds.), Bioremediation of the Contaminated Soils. Agronomy Series No. 37, ASA, CSSA, SSSA, Madison, Wisconson, USA, 1999; p.53-87.

[34] Liu, X.M., Wu, Q.T., Banks, M.K., Effect of simultaneous establishment of Sedum alfridii and Zea mays on heavy metal accumulation in plants. International Journal of Phytoremediation, 2005; 7(1):43-53. [doi:10.1080/16226510590915800

[35] Kabata-Pendias A., Pendias, H. Trace elements in soils and plants, Published by CRC Press, Boca Raton, USA. 1992; 365 p.

[36] Galfata, I., Bilal, E. Beji Sassi, A., Abdallah, H., Zaier, A. Accumulation of heavy metals in native plants growing near the phosphate treatment industry, Tunisia. Journal of Earth and Environmental Sciences, 2013; 6 (2): 85-100. 
[37] Fitz, W.J., Wenzel W.W. Arsenic transformation in the soil-rhizosphere-plant system, fundamentals and potential application of phytoremediation, Journal of Biotechnology, 2002; 99: 259-78.

[38] Yoon, Y., Cao X., Zhou Q., Ma L.Q. Accumulation of $\mathrm{Pb}, \mathrm{Cu}$, and $\mathrm{Zn}$ in native plants growing on a contaminated Florida site, Science of Total Environment, 2006; 368: 456-464.

[39] Baker, A.J.M., Brooks, R.R. Terrestrial higher plants which hyperaccumulate metallic elements - a Review of their distribution, ecology and phytochemistry, Biorecovery, 1989; 1: 81-126.

[40] Duruibe, J.O., Ogwuegbu, M.O.C., Egwurugwu, J.N. Heavy metal pollution and human toxic effects. International Journal of Physical Sciences, 2007; 2(5): 112-118.

[41] Lars, J. Hazards of heavy metal contamination. British Medical Bulletin, 2003; 68: 167-182.

[42] Friends of Nature. The IT industry has a critical duty to prevent heavy metal pollution. 2010 Study of heavy metal pollution by IT brand supply chain. Institute of Public and Environmental Affairs, Green Beagle, April, 2010, 17pp

[43] Jung, M. C. Heavy metal concentrations in soils and factors affecting metal uptake by plants in the vicinity of a Korean Cu-W mine. Sensors, 2008; 8: 2413-2423.

[44] Nwachukwu, O.I., Agbede, O.O. Plant bioaccumulation and root-to-shoot transport of metals in a field soil contaminated by mining activities. PAT 2010; 5(2): 309-319.

[45] Guala, S.D., Vega, F. A., Covelo, E. F. The dynamics of heavy metals in plant-soil interaction. Ecological Modelling, 2010; 221: 1148-1152.

[46] Addo, M.A., Darko, E.O., Gordon, C., Nyarko, B.J.B., Gbadago, J.K., Nyarko, E., Affum, H.A., Botwe, B.O. Evaluation of heavy metals contamination of soil and vegetation in the vicinity of a cement factory in the Volta Region, Ghana. International Journal of Science and Technology, 2(1): 40-50.

[47] Nouri, J., Khorasani, N., Lorestani, B., Karami, M., Hassani, A.H., Yousefi, N. Accumulation of heavy metals in soil and uptake by plant species with phytoremediation potential. Environmental and Earth Sciences, 2009; 59, 315-323.

[48] Kotrba, P., Najmanova, J., Macek, T., Rumi, T., Mackova, M. Genetically modified plants in phytoremediation of heavy metal and metalloid soil and sediment pollution. Biotechnology Advances, 2009; doi:10.1016/j.biotechadv.2009.06.003. 12ppwww.elsevier.com/locate/biotechadv 
